\title{
Intercomparison of aircraft instruments on board the C-130 and Falcon 20 over southern Germany during EXPORT 2000
}

\author{
N. Brough ${ }^{1}$, C. E. Reeves ${ }^{1}$, S. A. Penkett ${ }^{1}$, D. J. Stewart ${ }^{1}$, K. Dewey ${ }^{2}$, J. Kent $^{2}$, H. Barjat ${ }^{2}$, P. S. Monks ${ }^{3}$, H. Ziereis ${ }^{4}$, \\ P. Stock ${ }^{4}$, H. Huntrieser ${ }^{4}$, and H. Schlager ${ }^{4}$ \\ ${ }^{1}$ School of Environmental Sciences, University of East Anglia, Norwich, UK \\ ${ }^{2}$ Meteorological Research Flight (MRF), Atmospheric Chemistry Group, UK Meteorological Office, Bracknell, UK \\ ${ }^{3}$ Department of Chemistry, University of Leicester, Leicester, UK \\ ${ }^{4}$ Institute für Physik der Atmosphäre, Deutsches Zentrum für Luft- und Raumfahrt (DLR), Oberpfaffenhofen, Germany
}

Received: 17 June 2003 - Published in Atmos. Chem. Phys. Discuss.: 15 July 2003

Revised: 28 November 2003 - Accepted: 28 November 2003 - Published: 3 December 2003

\begin{abstract}
In the summer 2000 EXPORT aircraft campaign (European eXport of Precursors and Ozone by long-Range Transport), two comprehensively instrumented research aircraft measuring a variety of chemical species flew wing tip to wing tip for a period of one and a quarter hours. During this interval a comparison was undertaken of the measurements of nitrogen oxide (NO), odd nitrogen species $\left(\mathrm{NO}_{\mathrm{y}}\right)$, carbon monoxide $(\mathrm{CO})$ and ozone $\left(\mathrm{O}_{3}\right)$. The comparison was performed at two different flight levels, which provided a 10fold variation in the concentrations of both NO (10 to 1000 parts per trillion by volume (pptv)) and $\mathrm{NO}_{\mathrm{y}}(200$ to over 2500 pptv). Large peaks of $\mathrm{NO}$ and $\mathrm{NO}_{\mathrm{y}}$ observed from the Falcon 20, which were at first thought to be from the exhaust of the C-130, were also detected on the 4 channel $\mathrm{NO}_{\mathrm{xy}}$ instrument aboard the $\mathrm{C}-130$. These peaks were a good indication that both aircraft were in the same air mass and that the Falcon 20 was not in the exhaust plume of the C-130. Correlations and statistical analysis are presented between the instruments used on the two separate aircraft platforms. These were found to be in good agreement giving a high degree of correlation for the ambient air studied. Any deviations from the correlations are accounted for in the estimated inaccuracies of the instruments. These results help to establish that the instruments aboard the separate aircraft are reliably able to measure the corresponding chemical species in the range of conditions sampled and that data collected by both aircraft can be co-ordinated for purposes of interpretation.
\end{abstract}

\section{Introduction}

Atmospheric chemistry instruments have improved in the last ten years, moving towards better detection limits of single

Correspondence to: C. E. Reeves

(c.reeves@uea.ac.uk) parts per trillion by volume (pptv) levels in measurements of compounds such as nitrogen oxides $\left(\mathrm{NO}+\mathrm{NO}_{2}=\mathrm{NO}_{\mathrm{x}}\right)$ and the sum of reactive nitrogen compounds $\left(\mathrm{NO}_{\mathrm{y}}\right)$ (Ridley et al., 2000). Aircraft platforms have added another dimension to the overall chemical picture of the atmosphere but bring with them additional technical and chemical challenges such as inlets, pressure, temperature effects, humidity and instrument warm up periods. Consequently, instrument performance can often be downgraded on an aircraft platform and it is therefore necessary to qualitatively assess the performance of instruments on such platforms. One way of testing instrument performance is by comparison with a similar instrument whilst measuring the same air mass. Such comparisons are necessary to establish reliability of instruments allowing quantitative estimates of the accuracy and precision.

Various comparison exercises have been undertaken during ground-based campaigns, involving a range of instruments, (e.g. Williams et al., 1998; Fehsenfeld et al., 1990; Zenker et al., 1998) at various sites throughout the world. Aircraft comparisons on the other hand, have been performed far less frequently (e.g. Ridley et al., 1988; Ziereis et al., 1990) and have involved atmospheric instruments that measure $\mathrm{NO}, \mathrm{NO}_{\mathrm{y}}$, carbon monoxide $(\mathrm{CO})$ and ozone $\left(\mathrm{O}_{3}\right)$. Although aircraft campaigns over the last 20 years have increased in frequency, instrument performance especially when considering a $\mathrm{NO}_{\mathrm{xy}}$ instrument, is found to be poorer than similar ground based field deployment owing in the main to the short period ( $4 \mathrm{~h}$ or less) of instrument warmup and therefore stabilisation. Many aircraft campaigns have therefore taken place without knowing the true precision, accuracy and capabilities of the instrument on the particular flight. The more instruments involved in comparisons the better the instrument integration, as can be clearly seen in the ground-based study by Williams et al. (1998) in which seven $\mathrm{NO}_{\mathrm{y}}$ instruments were compared. 


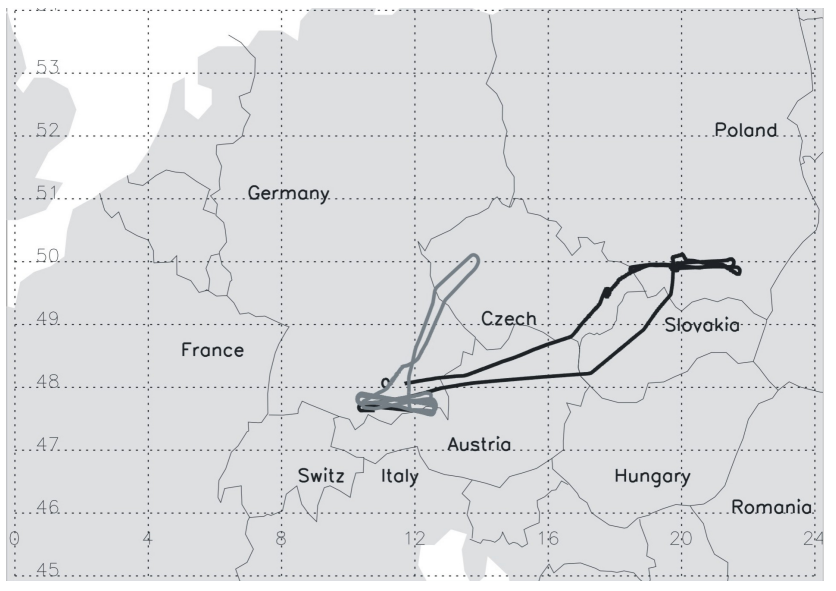

Fig. 1. Flight paths of the DLR Falcon 20 (light grey) and the MRF C-130 (dark grey) on 10 August 2000. The intercomparison legs were flown along a straight track between $47.97^{\circ} \mathrm{N}, 12.67^{\circ} \mathrm{W}$ and $47.63^{\circ} \mathrm{N}, 12.39^{\circ} \mathrm{W}$.

To obtain a good instrument comparison it is advisable that the mixing ratios of the compounds to be measured are not consistently near to the detection limits of the instruments, as this can result in erroneous statistical analysis. However, it is important to test instrument behaviour through intercomparison exercises at both high and low ambient mixing ratios. A variety of structures within the air mass to be measured are preferred to ensure that there is a high degree of dynamic variability giving large changes in concentration on all instruments. On the ground, changes in the wind direction help to vary the air parcel concentrations and assist in obtaining a large dynamic concentration range. In an aircraft, this can usually be achieved by changing the aircraft altitude since much of the troposphere is very stratified with narrow layers of different chemical composition, in particular the water vapour concentration (Newell et al., 1996; Penkett et al., 1995). The work in this paper describes the comparison of five different instruments onboard two different aircraft during the EXPORT campaign of August 2000.

\section{Experimental}

Aircraft measurements of important atmospheric constituents namely, $\mathrm{CO}, \mathrm{NO}, \mathrm{NO}_{\mathrm{y}}$ and $\mathrm{O}_{3}$ were measured in-situ and simultaneously onboard two separate aircraft Deutsches Zentrum für Luft- und Raumfahrt (DLR) Falcon 20 and the Meteorological Research Flight (MRF) C-130). The aircraft were based at the DLR, Oberpfaffenhofen airport in southern Germany during August 2000 and took part in the EXPORT (European eXport of Precursors and Ozone by long-Range Transport), project. The EXPORT program consisted of a series of flights under a range of synoptic conditions designed to characterise the chemical composition of air over Europe and to quantify the potential of precur- sors exported from Europe to produce $\mathrm{O}_{3}$ downwind. Standard instrumentation such as the meteorological parameters (static pressure, wind direction and speed, air temperature, dew point temperature, total water content, etc) were measured on the MRF C-130 as detailed by Hov et al. (2000). The comparison flight took place on 10 August 2000 and the flight details are shown in Fig. 1.

Most instruments were similar in their methods of detection. $\mathrm{NO}$ and $\mathrm{NO}_{\mathrm{y}}$ used detection by chemiluminescence of $\mathrm{NO}$ and $\mathrm{O}_{3}, \mathrm{CO}$ by vacuum-UV resonance fluorescence (Gerbig et al., 1996, 1999) and $\mathrm{O}_{3}$ was measured by UV absorption.

On the ground, pre-flight calibration comparisons were performed for the two $\mathrm{NO}$ and $\mathrm{NO}_{\mathrm{y}}$ instruments. Calibrations were first performed with individual compressed gas NO standards and then these were cross-referenced with each other's standard. The calibration gases varied in concentration and were described by the manufacturers (see later) to be $1.01 \pm 0.01$ parts per million by volume (ppmv) and $3.5 \pm 0.2$ ppmv. It was found that the accuracy of the instruments to the different calibration gases was within 3\%, showing that on the ground at least, the instruments were able to measure the same mixing ratios. Since the C-130 $\mathrm{NO}_{\mathrm{xy}}$ can only operate up to an altitude of $9000 \mathrm{~m}$ before sample flow problems (Bauguitte, 2000) are encountered the intercomparison portion of the flight was therefore carried out at altitudes of ca. 8000 and ca. $6000 \mathrm{~m}$ with the assumption that we would obtain air of different compositions during this period. Rendezvous of the two aircraft was at the higher altitude and at a position over southern Germany $\left(47^{\circ} \mathrm{N}, 12^{\circ} \mathrm{E}\right)$. The two aircraft flew as close to each other as safety permitted. The horizontal and vertical separation was estimated to be of the order of 70 and $5 \mathrm{~m}$ respectively and was held for a period of $1.25 \mathrm{~h}$ at an indicated aircraft speed (IAS) of 180 knots moving through $410 \mathrm{~km}$ of air (dependent on wind speed and direction). At the conclusion of the first leg at the pressure altitude of $8000 \mathrm{~m}$ ( $40 \mathrm{~min})$, the aircraft was manoeuvred into a slow descent to an altitude of ca. $600 \mathrm{~m}$. This lower flight level was maintained for a further $30 \mathrm{~min}$ until both aircraft broke from the formation. The intercomparison legs were flown along a straight track between $47.97^{\circ} \mathrm{N}, 12.67^{\circ} \mathrm{W}$ and $47.63^{\circ} \mathrm{N}, 12.39^{\circ} \mathrm{W}$ with three turns and time was allowed at specified periods throughout each leg for the relevant instrument zeros and calibrations. During the comparison no clouds were encountered at the relevant flight levels; broken stratocumulus was observed beneath the aircraft and the sky was clear above. All instruments that were involved with the intercomparison appeared to function correctly and there was no verbal in-flight discussion of concentration profiles.

\subsection{NO, $\mathrm{NO}_{\mathrm{y}}$ measurements by the University of East An- glia (UEA) on the C-130}

Measurements of the oxides of nitrogen on the C-130 were obtained by chemiluminescence pioneered by Kley and Mc- 
Farland (1980) and the light produced measured by a cooled, red sensitive photomultiplier tube (PMT) (Hübler et al., 1992; Drummond et al., 1988). Detection of NO was achieved by sampling air at $1 \mathrm{~L} \mathrm{~min}^{-1}$ at standard temperature and pressure (STP) from a rear facing stainless steel tube (to help exclude aerosols of radius $>1 \mu \mathrm{m}$ ) lined with $1 / 4^{\prime \prime}$ (6 mm outside diameter) PFA (Perfluoroalkoxy) which was outside the pressure boundary of the aircraft layer and forward of the propellers. The sampled air was mixed with humidified $\mathrm{O}_{3}$ on entering the gold plated reaction vessel. $\mathrm{NO}_{\mathrm{y}}$ detection was achieved by reducing it to $\mathrm{NO}$ using $\mathrm{CO}$ as a catalyst $(0.3 \% \mathrm{v} / \mathrm{v})$ in gold tubes which were $35 \mathrm{~cm}$ in length with an inner diameter of $5 \mathrm{~mm}$ and maintained at $300^{\circ} \mathrm{C}$ (Fahey et al., 1985). The sampling inlet used for $\mathrm{NO}_{y}$ measurements was made of perfluroalkoxy (PFA) teflon and enclosed in a tear drop shaped assembly connected to the aircraft skin situated perpendicular to the direction of flight. The inlet and its orientation was specifically designed to minimise $\mathrm{NO}_{\mathrm{y}}$ loss and consequently had a low-volume permitting fast sampling (Ryerson et al., 1999). It was heated to $75^{\circ} \mathrm{C}$ which also helped to reduce potential $\mathrm{HNO}_{3}$ wall losses (Neuman et al., 1999) before the $1 \mathrm{~L} \mathrm{~min}^{-1}$ STP sampled air reached the heated converter. The response speed of the converters was faster than $1 \mathrm{cps}$ (counts per second). All overflow and calibration gases entering the $\mathrm{NO}_{\mathrm{y}}$ system passed through the inlet.

Four calibrations of the two detectors were performed, one each, pre and post flight as well as two in-flight using a standard concentration of $\mathrm{NO}$ in $\mathrm{N}_{2}$ (BOC specialty gases) of $1.01 \pm 0.01$ ppmv. Stable air masses in which no clouds were present and $\mathrm{NO}$ and $\mathrm{NO}_{\mathrm{y}}$ varied little were sought over the calibration period (10-15 min) and were often found in free tropospheric air above $4000 \mathrm{~m}$. The NO standard was diluted into the $1 \mathrm{~L} \mathrm{~min}^{-1} \mathrm{STP}$ sample air stream at a rate of $3 \mathrm{~cm}^{3} \mathrm{~min}^{-1}$ STP by means of a mass flow controller (Tylan) yielding a resulting mixing ratio of $3.3 \mathrm{ppbv}$ NO. Linear interpolations between the in-flight calibrations were used to provide minimal error. $\mathrm{NO}_{2}$ calibrations on the $\mathrm{NO}_{\mathrm{y}}$ converter were made by photolysing zero grade air, producing $\mathrm{O}_{3}$, which reacted with the $\mathrm{NO}$ calibration gas to obtain a $90 \%$ conversion to $\mathrm{NO}_{2}$. The sensitivity of the NO channel was $6.1 \pm 0.1 \mathrm{cpspptv}^{-1}$ and for the $\mathrm{NO}_{2}$ sensitivity on the $\mathrm{NO}_{\mathrm{y}}$ channel was $3.4 \pm 0.2 \mathrm{cps} \mathrm{pptv}^{-1}$. The conversion efficiency of $\mathrm{HNO}_{3}$ to $\mathrm{NO}$ in the gold converters occurs with an efficiency greater than $90 \%$ in the UEA instrument, under the same conditions there is no detectable conversion of $\mathrm{N}_{2} \mathrm{O}$ to NO. Ammonia is converted with an efficiency of $<5 \%$ in this system and the conversion of HCN occurs with an efficiency of $8 \%$ in totally dry air but these efficiencies decrease substantially with relative humidity. The DLR group have performed conversion efficiency tests on their $\mathrm{NO}_{\mathrm{y}}$ converter for $\mathrm{HCN}, \mathrm{N}_{2} \mathrm{O}, \mathrm{CH}_{3} \mathrm{CN}$ and $\mathrm{NH}_{3}$. Of these only $\mathrm{HCN}$ was a possible source of interference of around $2 \%$ under the conditions of the intercomparison.

When zeroing, instead of the $\mathrm{O}_{3}$ being added directly into
Table 1. Detection limits ( $2 \sigma)$ and estimated accuracies of the UEA $\mathrm{NO}_{\text {xy }}$ system for $10 \mathrm{~s}$ data.

\begin{tabular}{ccc}
\hline Channel & $\begin{array}{c}\text { Detection limit } \\
(2 \sigma) / \mathrm{pptv}\end{array}$ & $\begin{array}{c}\text { Estimated accuracies at } \\
\text { ambient (pptv) level }\end{array}$ \\
\hline $\mathrm{NO}$ & $3-4$ & $\pm 12 \%$ at 50 \\
$\mathrm{NO}_{\mathrm{y}}$ & $3-4$ & $\pm 21 \%$ at 450 \\
\hline
\end{tabular}

the reaction vessel as in the measurement mode, a relaxation volume (Pyrex bottle of $250 \mathrm{ml}$ volume) was used. In this case, the $\mathrm{O}_{3}$ was added to the sample matrix prior to injection into the gold plated reaction chamber and $\mathrm{NO}_{2}$ chemiluminescence occurs away from the photomultiplier tube. The resulting background or zero signal was a combination of the photomultiplier dark counts and interference from stray chemiluminescence of atmospheric species and catalysed reactions on the chamber walls (Drummond et al., 1985). The background signal was found to be $400 \pm 7 \mathrm{cps}$ for $\mathrm{NO}$, and $280 \pm 9 \mathrm{cps}$ for $\mathrm{NO}_{\mathrm{y}}$ and was performed at the beginning and end of every flight level for a period dependant on the instrument performance but usually between 90 and $120 \mathrm{~s}$.

Artifacts, which are the difference between the measured and zero signal mode when there is supposedly no nitrogen oxide present were performed during take-off and landing by overflowing the sample lines with $2 \mathrm{~L} \mathrm{~min}^{-1}$ STP of synthetic zero grade compressed air (BOC, British Oxygen Company). These two measurements were averaged and found to be of the order, $15 \pm 9 \mathrm{cps}$ and $212 \pm 20 \mathrm{cps}$, for NO and $\mathrm{NO}_{\mathrm{y}}$ respectively. Conversion efficiency of the $\mathrm{NO}_{\mathrm{y}}$ converters using $\mathrm{NO}_{2}$ as a surrogate were found to be $>90 \%$ for both in-flight measurements.

Detection limits (LOD) were estimated using the $1 \sigma$ counting precision of the $1 \mathrm{cps}$ zero background signal which was assumed to represent the detection limit (see Ridley et al., 1994) as there are no suitable invariant ambient data. Using the corresponding $\mathrm{NO}_{2}$ sensitivities (NO sensitivity $\times$ conversion efficiency), the standard deviations of the zero data for the other channels (cps) were transformed to pptv and it can be assumed that when the data is averaged to $10 \mathrm{~s}$ the LOD would improve by $\frac{1}{\sqrt{10}}$. The $2 \sigma$ detection limits are shown in Table 1. Data were collected at 1ćps intervals for all channels but were averaged to $10 \mathrm{~s}$ owing to other instrument parameters.

The major contributor to the inaccuracy for each detector was the instrument artifact signal. The sum of the inaccuracy and imprecision of a single measurement gives the overall uncertainty of the instrument. Estimated accuracies were accounted for as: (1) Uncertainties in the flow meter calibrations for the sample and calibration gas flows of $4 \%$ (a bubble flow meter was used to calibrate pre and post campaign). (2) Calibration of the gas standard uncertainty based upon the intercomparison with the DLR standard (3 ppmv NO in 
Table 2. Detection limits $(2 \sigma)$ and estimated accuracies of the DLR $\mathrm{NO}$ and $\mathrm{NO}_{\mathrm{y}}$ system for $10 \mathrm{~s}$ data.

\begin{tabular}{ccc}
\hline Channel & $\begin{array}{c}\text { Detection limit } \\
(2 \sigma) / \mathrm{pptv}\end{array}$ & $\begin{array}{c}\text { Estimated accuracies at } \\
\text { ambient (pptv) level }\end{array}$ \\
\hline $\mathrm{NO}$ & $1-2$ & $\pm 8 \%$ at 50 \\
$\mathrm{NO}_{\mathrm{y}}$ & $1-2$ & $\pm 7 \%$ at 450 \\
\hline
\end{tabular}

$\mathrm{N}_{2}$ ) of 3\%. (3) Average measured artifact uncertainty for the flight. The accuracy of the UEA instrument is comparable to the reported inaccuracies in similar instruments, for example Williams et al. (1997) quote estimated inaccuracies of $19 \%$ in $\mathrm{NO}$ and $15 \%$ in $\mathrm{NO}_{\mathrm{y}}$ and Parrish et al. (1993) quote an inaccuracy of $15 \%$ in their $\mathrm{NO}_{\mathrm{y}}$ data. Using a similar technique with a molybdenum catalyst Stehr et al. (2000) report an inaccuracy in their $\mathrm{NO}_{\mathrm{y}}$ measurements of $30 \%$ and Kondo et al. (1997) quote an error of $12 \%$ in NO at 50 pptv and $27 \%$ in $\mathrm{NO}_{\mathrm{y}}$ at 100 pptv.

Variability of the sensitivities was shown on all UEA $\mathrm{NO}_{\mathrm{xy}}$ channels during this flight and is known as the precision of the instrument. The scatter $(1 \sigma)$ that was exhibited between the two in-flight sensitivities was $1.89 \%$ for NO (lower than that expected on the basis of instrument diagnostics) and $14.1 \%$ for $\mathrm{NO}_{2}$ sensitivities on the $\mathrm{NO}_{\mathrm{y}}$ channel. These high values for the $\mathrm{NO}_{\mathrm{y}}$ channel was mainly due to rapid changes during calibration of the ambient $\mathrm{NO}_{\mathrm{y}}$ levels leading to overestimated calibration averages as well as systematic contamination owing to large pollution episodes experienced by the $\mathrm{NO}_{\mathrm{y}}$ converter leading to a reduced sensitivity post flight.

2.2 $\mathrm{NO}$ and $\mathrm{NO}_{\mathrm{y}}$ measurements by DLR instruments on the Falcon 20

The technique for the measurement of $\mathrm{NO}$ and $\mathrm{NO}_{\mathrm{y}}$ on board the Falcon 20 is quite similar to that one used on the C-130 as mentioned previously. A two-channel chemiluminescence detector for $\mathrm{NO}$ was used allowing the simultaneous detection of $\mathrm{NO}$ and $\mathrm{NO}_{\mathrm{y}} . \mathrm{NO}_{\mathrm{y}}$ was measured by the catalytic conversion technique already mentioned above. There are only a few differences between the $\mathrm{NO}$ and $\mathrm{NO}_{\mathrm{y}}$ measurements on the two aircraft. The DLR chemiluminescence detector is operated with a sample flow of $1.5 \mathrm{~L} \mathrm{~min}^{-1}$ at STP. Sampling occurs through a rear-facing inlet to avoid sampling of large aerosol particles onto the $\mathrm{NO}_{\mathrm{y}}$ converter. All sampling lines are made of PFA and are heated to about 30$40^{\circ} \mathrm{C}$. The gold tube used on the $\mathrm{NO}_{\mathrm{y}}$ converter during EXPORT was $60 \mathrm{~cm}$ long with an inner diameter of $4 \mathrm{~mm}$. A $\mathrm{CO}$ reducing agent was added upstream of the converter at $3 \mathrm{~cm}^{3} \mathrm{~min}^{-1}$ STP.

Sensitivity checks of the two NO detectors were determined before and after each flight by adding a standard concentration of $\mathrm{NO}$ in $\mathrm{N}_{2}$. The NO-standard was diluted into the NO-free zero air by means of a mass flow controller. Usually four different NO mixing ratios were used between 1 and 8 ppbv. The sensitivity of the two NO-channels was 21 and $18 \mathrm{cps} \mathrm{pptv}^{-1}$. The background signal of the two NO detectors were determined in a similar way as described previously on the C-130. The background signal was determined every $10 \mathrm{~min}$ for about $1 \mathrm{~min}$. It was about $1000 \mathrm{cps}$ in both channels.

The conversion efficiency of the gold converter was checked before and after each flight by adding known amounts of $\mathrm{NO}_{2}$ produced by gas phase reaction of $\mathrm{NO}$ with $\mathrm{O}_{3}$. The conversion efficiency did not vary significantly during the campaign and was close to $100 \%$. Zero air artifacts were also determined, in a similar way as described for the UEA instrument, before and after each flight and also during the flights itself. The zero air artifacts for $\mathrm{NO}$ and $\mathrm{NO}_{\mathrm{y}}$ were of the order of $3 \pm 1$ pptv and $28 \pm 6$ pptv, respectively. Owing to space limitations on the FALCON 20, which is a smaller aircraft, no sensitivity checks could be performed during the flights. The detection limits and estimated accuracies of the instrument are shown in Table 2.

\subsection{Ozone measurements by UKMO on the C-130}

A commercial instrument was used to measure $\mathrm{O}_{3}$ (Thermo Environmental Instruments Inc. model 49 U.V. Photometric Ozone Analyser) on the $\mathrm{C}-130$. It has been modified with the addition of a drier and separate pressure and temperature sensors. The inlet from the port air sample pipe is pumped via a buffer volume to maintain the inlet air at near surface pressure. All surfaces in contact with the sample including the pump are of Polytetrafluoroethylene (PTFE) or PFA. The instrument has a range of $0-2000 \mathrm{ppbv}$, a detection limit of $1 \mathrm{ppbv}$ and a linearity of $2 \%$ (as stated by the manufacturer). The data are sampled with a frequency of 1 cps then smoothed over a $5 \mathrm{~s}$ period. The calibration is carried out annually against a traceable standard from the National Physics Laboratory (NPL). Biannual checks are carried out locally against a transfer standard (DASIBI). The calibrations have consistently shown the repeatability of the instrumental method. No discernible drift (less than 2\%) was found between calibrations. Hence an accuracy of $2 \%$ is expected from the calibration with an NPL guarantee of less than $1 \%$ on the precision. Laboratory experiments have shown no discernible loss of $\mathrm{O}_{3}$ on inlet lines (i.e. less than $1 \%)$.

After the EXPORT campaign it was discovered that there was a problem with the recording of the temperature sensor data on the $\mathrm{C}-130 \mathrm{O}_{3}$ instrument. A total of 40 flights, preEXPORT and post-EXPORT, where temperature data was recorded, were analysed. The ozone temperature and pressure are recorded, in order to normalise for changes in sample mass, as the sample is not kept at a constant pressure and temperature. The temperature was found to vary by only $12 \mathrm{~K}$ (1): from 304 to $316 \mathrm{~K}$. A whole range of flights were 
studied from winter to summer, from low level to high level, from the Azores to the Arctic, via, Tenerife, Greece, Austria, Germany and the UK. Most flight data taken as representative of European summer conditions varied between 306 and $312 \mathrm{~K}$. Hence, $309 \mathrm{~K}$ was chosen to represent the sample temperature for all of the EXPORT flights. With $309 \mathrm{~K}$ as the mid-point, it is most likely that the temperature will only vary by $\pm 3 \mathrm{~K}$ during flight i.e. the $\mathrm{O}_{3}$ precision and accuracy will vary by $\pm 1 \%$. However, erring on the side of caution, if the temperature variation is equal to the largest range found (304 to $316 \mathrm{~K}$ ) the error on the $\mathrm{O}_{3}$ reading would be $\pm 2 \%$. Even if the temperature varied from $309 \mathrm{~K}$ by $\pm 12 \mathrm{~K}$ (i.e. from $297-$ $321 \mathrm{~K}$ ), which is most unlikely, considering the existing good data, the error would still only be $\pm 4 \%$. Considering all possible sources of error the $\mathrm{O}_{3}$ data is good to within $\pm 5 \%$ or better.

\subsection{Ozone measurements by DLR on the Falcon 20}

$\mathrm{O}_{3}$ was also measured using an UV absorption photometer (Thermo-Environmental, Model 49). Sampling and detection of $\mathrm{O}_{3}$ occurs at ambient pressure through a rear-facing inlet at a frequency of $0.25 \mathrm{cps}$. Inlet and inlet lines were made of PFA. Separate pressure and temperature sensors measured pressure and temperature inside the $\mathrm{O}_{3}$ analyser. The data were sampled at $1 \mathrm{cps}$ but smoothed over a $4 \mathrm{~s}$ period.

The sensitivity of the UV absorption photometer was checked several times during the EXPORT campaign with an $\mathrm{O}_{3}$ standard source (Environment s.a. Model $\mathrm{O}_{3} 41 \mathrm{M}$ ). No significant variation of the sensitivity of the $\mathrm{O}_{3}$ instrument was found during these calibrations. The $\mathrm{O}_{3}$ standard source was compared with $\mathrm{O}_{3} \mathrm{UV}$ absorption measurements at the global watch station at Hohenpeißenberg, Germany. The analyser has a range of $0-1000 \mathrm{ppbv}$ and a detection limit of about $1 \mathrm{ppbv}$. The major contributor to the uncertainty of the detector is the accuracy of the signal output of the instrument. As the accuracy of the signal output remains constant the uncertainty of the instrument increases with decreasing pressure in the absorption cell. During the comparison the overall uncertainty of the $\mathrm{O}_{3}$ analyser was between 4 and $5 \%$.

2.5 Carbon monoxide measurements by UKMO on the C130

A detailed description of the $\mathrm{CO}$ instrument on the C-130 can be found in Gerbig et al. (1999). It consists of three principle components: a resonance excitation source, an optical filter, and a sample fluorescence detection cell. The appropriate wavelength interval for the excitation light around $150 \mathrm{~nm}$ is selected in an $\mathrm{N}_{2}$ purged optical filter consisting of two dielectric coated mirrors in combination with two $\mathrm{CaF}_{2}$ lenses, which image the lamp into the fluorescence chamber. Fluo- rescence of $\mathrm{CO}$ is detected with a PMT at right angles to the excitation radiation.

The sample gas is taken from the starboard air-sampling pipe (ASP) which is pressure regulated and allows operation at ambient pressures between 1013 and 175 mbar. The connection to the ASP is by a PFA tube with $1 / 8^{\prime \prime}$ OD and a length of about $15 \mathrm{~m}$. The sampled air is dried by passing it over Drierite $\left(\mathrm{CaSO}_{4}\right.$ with humidity indicator) to avoid interference of atmospheric water vapour owing to absorption of the fluorescence radiation (a mixing ratio of $2 \% \mathrm{H}_{2} \mathrm{O}$ causes a decrease in the fluorescence signal of $10 \%$ ).

In-situ calibration of the instrument is accomplished by injecting a known standard (515 ppbv of $\mathrm{CO}$ in air), at flow rates slightly higher than the sample flow rate, into the sampling line close to the control valve. For determination of the background signal, the calibration standard is passed through a Hopcalite scrubber, which quantitatively removes the $\mathrm{CO}$ to levels $<1 \mathrm{ppbv}$. In-flight calibrations and zeros lasting roughly $4 \mathrm{~min}$ were performed approximately every $30 \mathrm{~min}$. The sensitivity was found to be $31 \mathrm{cpsppbv}^{-1}$, which is less than half the sensitivity for this instrument quoted by Holloway et al. (2000) $\left(73 \mathrm{cps} \mathrm{ppbv}^{-1}\right)$. The instrument background was found to be $55 \mathrm{ppbv}$ (in equivalent $\mathrm{CO} \mathrm{ppbv}$ units). Hence, following the analysis of Gerbig et al. (1999), the instrument detection limit is smaller than $6 \mathrm{ppbv}$ and the precision $1.5 \mathrm{ppbv}$. The instrument has also been shown to give a linear response from 0 to $100 \mathrm{ppmv}$ and has a time resolution of $1 \mathrm{~s}$. An aircraft instrument intercomparison has been conducted previously by Holloway et al. (2000), showing good agreement between the C-130 instrument and a VUV fluorescence instrument on board the US NOAA WP-3 aircraft.

2.6 Carbon monoxide measurements by DLR on the Falcon 20

The DLR CO instrument operated on the Falcon 20 is nearly identical to that one used on the $\mathrm{C}-130$. There are only some minor differences in the two instruments. In the DLR CO instrument the optical filter system is purged by argon instead of nitrogen and the instrument can be operated to less than 100 mbar. The sample gas is taken from an air inlet at the top of the fuselage and is passed through a sampling line made of stainless steel with $1 / 8^{\prime \prime}$ OD and length of about $1 \mathrm{~m}$. The sampled air is dried by a Perma Pure MD Gas DryerTM. Inflight calibration of the instrument is performed by injecting a known standard ( $\sim 1$ ppmv) into the sampling line. Detection limit, precision and time response is the same for both instruments. The DLR CO instrument has a linear response from 0 to 1000 ppmv. 


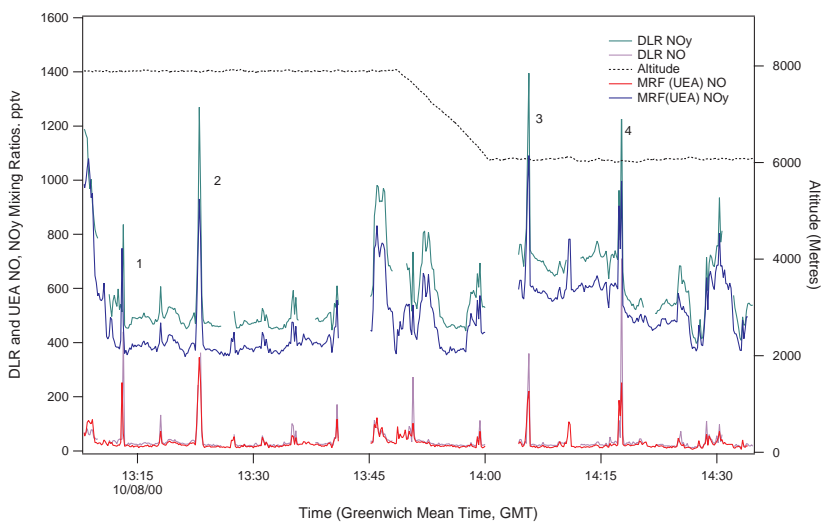

Fig. 2. The mixing ratios for $\mathrm{NO}$ and $\mathrm{NO}_{\mathrm{y}}$ observed at altitudes between 6000 and $8000 \mathrm{~m}$ during the comparison on the 10 August 2000 over southern Germany. The data sets have been averaged to $10 \mathrm{~s}$ from $1 \mathrm{~s}$ raw data and any gaps in the data are due to instrument zeroing or aircraft re-positioning.

\section{Results and discussion}

\section{1 $\mathrm{NO}$ and $\mathrm{NO}_{\mathrm{y}}$ measurements}

The data from the aircraft were placed on the databases at British Atmospheric Data Centre (BADC) and DLR for the UK and German contingents respectively. The C-130 and Falcon data sets (Fig. 2) were averaged to $10 \mathrm{~s}$ from $1 \mathrm{~s}$ raw data for both $\mathrm{NO}$ and $\mathrm{NO}_{\mathrm{y}}$. The air mass encountered for most of the time had little variation in the $\mathrm{NO}$ and $\mathrm{NO}_{\mathrm{y}}$ concentrations (less than $0.2 \% \mathrm{NO}_{\mathrm{y}}$ mixing ratio values greater than 1000 pptv) although large increases were observed in the $\mathrm{NO}$ and $\mathrm{NO}_{\mathrm{y}}$ instruments aboard both aircraft. These large increases in mixing ratios are referred to as spikes and usually lasted from a second to tens of seconds.

Large changes in the $\mathrm{NO}$ and $\mathrm{NO}_{\mathrm{y}}$ mixing ratios were recorded owing to the interception of polluted plumes almost certainly originating from aircraft. These large rapid changes were encountered four times and were observed on both the DLR and UEA NO and $\mathrm{NO}_{\mathrm{y}}$ channels, two at each flight level, giving half widths ranging from between 8 and $48 \mathrm{~s}$. At an indicated aircraft speed of 180 knots this would give plumes widths of between $0.7 \mathrm{~km}$ and $4.3 \mathrm{~km}$ if flying into the plume at $90^{\circ}$ to the long axis of the plume. The sharp peaks (labelled 1 to 4 in Fig. 2) were between 400 and 1000 pptv ( $1 \mathrm{~s}$ data with background averages of $20 \mathrm{pptv}$ ) on the NO instruments and between $1000 \mathrm{pptv}$ and $2600 \mathrm{pptv}$ ( $1 \mathrm{~s}$ data with background averages of 500 pptv) on the $\mathrm{NO}_{\mathrm{y}}$ instruments. Increases as large as 50 fold from the background air-mass mixing ratios were observed. The total increase in the $\mathrm{NO}_{\mathrm{y}}$ during these episodes cannot be fully accounted for by the increase in the NO mixing ratios. As the spikes occurred on both $\mathrm{NO}_{\mathrm{y}}$ instruments as well as the NO channels it can be assumed that they are elevated concentrations of NO as well as other $\mathrm{NO}_{\mathrm{y}}$ species and not an instrument irregular- ity observed on one channel owing to either static discharge or cosmic rays.

DLR measurements, on average, gave systematically higher apparent values than those of UEA ( $26 \mathrm{pptv}$ versus 20 pptv for $\mathrm{NO}$ and $555 \mathrm{pptv}$ versus $467 \mathrm{pptv}$ for $\mathrm{NO}_{\mathrm{y}}$ ) for $10 \mathrm{~s} \mathrm{NO}$ and $\mathrm{NO}_{\mathrm{y}}$ data. The scatterplots of $\mathrm{NO}$ and $\mathrm{NO}_{\mathrm{y}}$ (Figs. 3.1 and 3.2) display the mixing ratios with and without the spikes present in the data sets. This includes all the prominent peaks labeled 1, 2, 3, 4 in Fig. 2 as well as other sharp peaks greater than $100 \mathrm{pptv}$. Linear least squares fitting was applied to the data using a weighted bivariate regression routine (Neri et al., 1989). The inverse of the uncertainty of each data point was used as the weighting factor and $2 \sigma$ confidence limits are given with the regression coefficients. Figures 3.1a and 3.2a show the scattergram plots without the spikes of the $\mathrm{NO}$ and $\mathrm{NO}_{\mathrm{y}}$ respectively with a one to one line. Without the spikes the data sets for the NO instruments are highly correlated, a least squares fit correlation $\left(r^{2}\right)$ of 0.91 was observed. The slope was close to unity $(1.10 \pm 0.10)$ signifying a $10 \%$ difference in the mixing ratios of the two separate instruments. This observation is because of the differing NO sensitivities between the instruments and falls within the $12 \%$ uncertainty ( $12 \%$ at $50 \mathrm{pptv}$ ) of the UEA NO instrument. An intercept on the y-axis of just $3.8 \pm 0.2$ pptv suggests that there is a small systematic offset on the UEA technique and is most likely due to an instrument artifact problem. Examination of the $\mathrm{NO}_{\mathrm{y}}$ data sets with the peaks removed showed a high correlation $\left(r^{2}\right)$ of 0.97 with a slope of $1.17 \pm 0.06$. This $17 \%$ difference is well within the $22 \%$ combined uncertainty of the two instruments obtained by addition in quadrature. This suggests that no substantial unknown sources of error exist in either measurement. The intercept was again in the positive sector of the DLR data at $18.8 \pm 0.3 \mathrm{pptv}$, corresponding to $3-7 \%$ since most measurements were made in the 500-1000 pptv range. The tight correlation shown in both the $\mathrm{NO}$ and $\mathrm{NO}_{\mathrm{y}}$ plots (Figs. 3.1a and 3.2a) suggests that the instruments are in good agreement over the comparison period.

When the peaks are present (Fig. 3.1b and 3.2b) there are a few points that are scattered far from the line of best fit and $r^{2}$ was calculated as 0.81 for the NO data sets. A positive slope somewhat greater than unity $(1.29 \pm 0.03)$ with a small positive systematic offset of $1.2 \pm 0.1 \mathrm{pptv}$ was also found. This positive slope was about $19 \%$ greater than the NO data set with the peaks removed. Fitted slopes to the $\mathrm{NO}_{\mathrm{y}}$ data were higher with the peaks present, $1.22 \pm 0.01$ as compared to $1.17 \pm 0.06$, and an intercept of $-5.9 \pm 0.2 \mathrm{pptv}$ as shown in Fig. 3.2b. The correlation of 0.96 was roughly the same as the "spike-less" data (0.97) and was closer to one than previously obtained with the $\mathrm{NO}$ instruments indicating that the $\mathrm{NO}_{\mathrm{y}}$ spikes were in better agreement. The positive intercepts on Figs. $3.1 \mathrm{~b}$ and $3.2 \mathrm{~b}$ were relatively small, showing good instrument correlations at low mixing ratios. This poorer comparison of the data including the spikes is more likely to be due to sampling slightly different air (aircraft spatial 

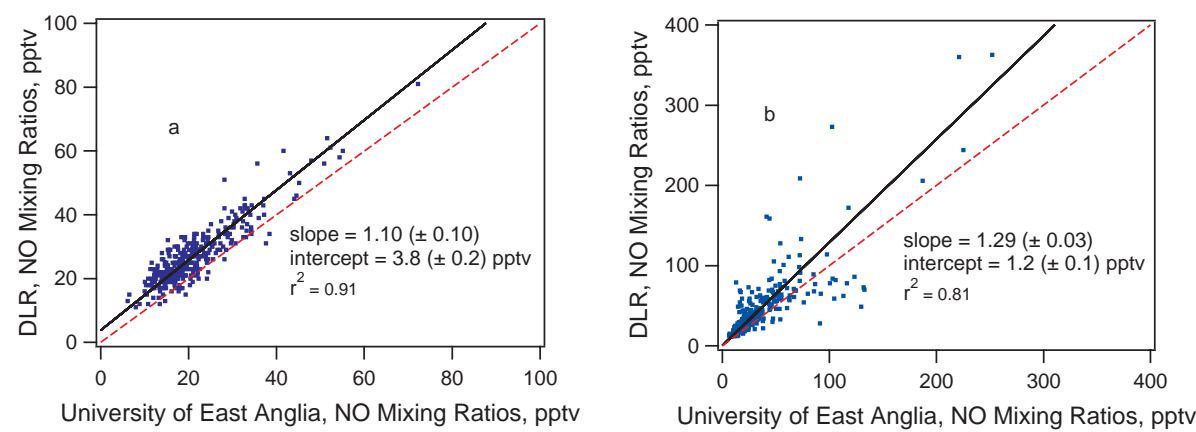

Fig. 3.1. Scattergram of all $10 \mathrm{~s}$ averaged NO mixing ratios, DLR versus UEA, (a) All spikes removed. (b) All data. Solid black lines in each plot show the bivariate linear regression fit to the data. The dashed line in each plot gives the one to one correspondence.
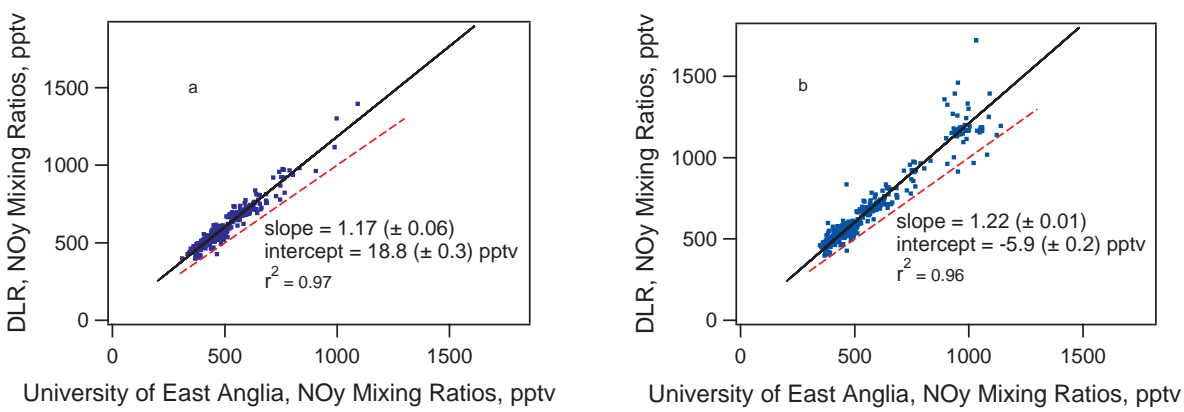

Fig. 3.2. Scattergram of all $10 \mathrm{~s}$ averaged $\mathrm{NO}_{\mathrm{y}}$ mixing ratios, DLR versus UEA, (a) All spikes removed. (b) All data. Solid black lines in each plot show the bivariate linear regression fit to the data. The dashed line in each plot gives the one to one correspondence.

arrangement), or slightly different temporal resolution of the two instruments than to instrument performance, which on the ground has been shown to be in close agreement. The spikes are clearly real plumes and are narrow; thus the observed concentrations on the two aircraft are likely to be different given their spatial arrangements.

Although the $\mathrm{NO}_{\mathrm{y}}$ measurements of the two instruments are in agreement within the uncertainties of the measurements, the systematically higher values of the DLR instrument ( $\sim 90$ pptv at 500 pptv) are such that care will have to be taken in using these measurements in the interpretation of "missing $\mathrm{NO}_{\mathrm{y}}$ " especially in light of the recent report of Day et al. (2003).

\section{$3.2 \mathrm{CO}$ and $\mathrm{O}_{3}$ measurements}

Only coincident data were used providing 433 points and corresponding to $90 \%$ coverage for the $\mathrm{CO}$ and 455 points and $89 \%$ coverage for the $\mathrm{O}_{3}$. The scattergram plot of the $\mathrm{CO}$ instruments with a corresponding one to one line and a weighted bivariate linear regression line fit is displayed in Fig. 4a. As displayed most data points are clustered around the two lines indicating that the data sets are in close agreement. This close proximity of the data sets is further validated by the high squared root correlation coefficient of 0.95 . Although the CO data sets were in fairly close agreement and within their respective accuracies for the whole com- parison period the slightly higher bivariate linear regression line at the lower concentration (50-70 ppbv) levels indicated that there was a systematic difference between the two instruments. In particular, the MRF CO instrument revealed a significant increase in $\mathrm{CO}$ from 68 to $75 \mathrm{ppbv}$ just after 13:33 GMT that persisted for ca. 3 min (Fig. 6). It was clearly not observed by the DLR instrument and would appear to indicate real variations in ambient $\mathrm{CO}$ since good agreement was obtained for the rest of the comparison period, although short term instability in one or other of the instruments cannot be fully ruled out during this period. Examination of the data sets for the first $30 \mathrm{~min}$ period gave a low slope gradient $(0.68 \pm 0.01)$ and poor correlation; $r^{2}=0.76$. Air mass sampling differences due to the spatial arrangement of the aircraft is the most likely cause since in the latter half of the comparison the data sets are in excellent agreement $\left(r^{2}=0.97\right)$. Low correlations $\left(r^{2}\right)$ over this initial $30 \mathrm{~min}$ period was also observed with the $\mathrm{O}_{3}$ data sets, 0.44 as compared to 0.96 , and shall be discussed in more detail later. From the $\mathrm{CO}$ scattergram plot of Fig. 4a, the systematic difference is evident in the fitted line parameters, the associated uncertainties of the slope was $0.95 \pm 1 \mathrm{ppbv}$, which is about $5 \%$ from unity. This level of systematic difference was also found with the intercomparison by Holloway et al. (2000) of a CO VUV fluorescence instruments and a TDLAS simultaneously operated and intercompared for CO on the NOAA WP-3 and the one used in this intercomparison aboard the MRF C-130 over the 

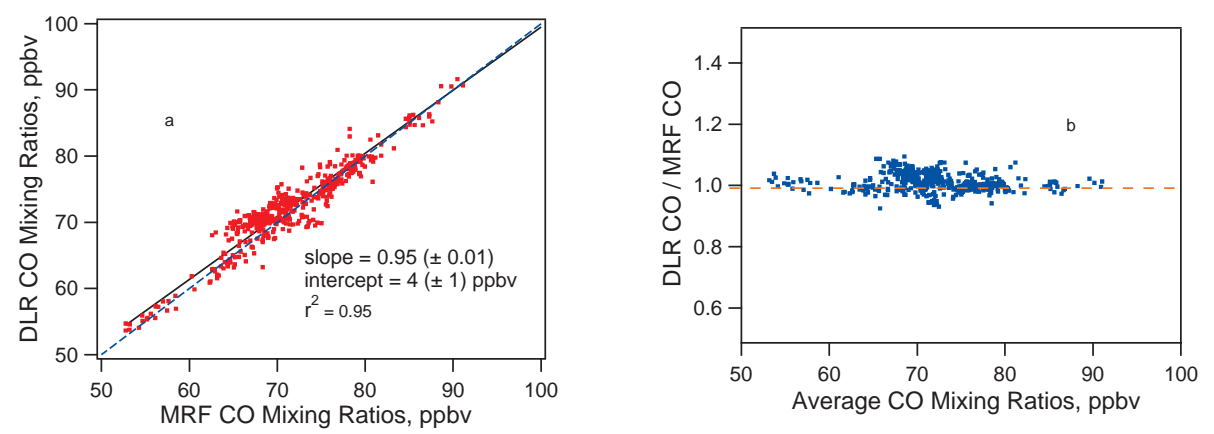

Fig. 4. Scattergram of DLR versus MRF CO mixing ratios shown in (a) and ratios of the two instruments against the average CO concentrations in (b). Below 50 ppbv no CO mixing ratios were found. Solid black lines in the plot show the weighted bivariate linear least squares fit to the data. All data is averaged to $10 \mathrm{~s}$. The dashed line gives the one to one correspondence.

central Atlantic. Using bivariate linear regression analysis a slope of $0.96 \pm 0.01$ was obtained with a correlation $\left(r^{2}\right)$ which was slightly higher and closer to unity than ours $(0.96$ as compared to 0.95). This reflects a small systematic difference in the accuracy of one or both of the instruments and artifacts on either instrument cannot be ruled out. The systematic offset on the other hand was found to be fairly high in comparison to the low mixing ratios encountered (roughly $5 \%$ of the average mixing ratio, $85 \mathrm{ppbv}$ ) with a positive intercept of $4 \pm 1 \mathrm{ppbv}$ on the DLR axis. This high intercept was most likely caused in the first $30 \mathrm{~min}$ at the higher level run in which poor agreement $\left(r^{2}=0.76\right)$, small dynamic range and large extrapolation from the main data set to the y-axis occurred.

In an attempt to further clarify the quantitative estimates of the precision and systematic differences another method is to use normalised difference versus the average data or the ratio of the two instruments against the overall average data. The ratio of the two $\mathrm{CO}$ measurements as a function of the average $\mathrm{CO}$ are displayed in Fig. 4b. Most of the points are tightly clustered around the 1.0 ratio line with $87 \%$ within $\pm 5 \%$ of the line. The standard deviation of the ratios of the measurements $(1 \sigma=2.2)$ is in close approximation to the square root of the sum of the squares of the precision $(1 \sigma=2.12)$ for each instrument suggesting that both instruments were measuring the same air-masses. Statistical analysis obtained a maximum ratio of 1.09 , a minimum of 0.92 and an average ratio value of $1.01 \pm 0.02$. The average ratio was found to be well within the systematic difference of $5 \%$, which was previously obtained with the bivariate linear least squares fit indicating that there are no long-term systematic variations between the instruments. Although the two CO ratios are spread evenly on either side of unity, the DLR data indicates higher CO concentrations around 70 ppbv. This can be accounted for in the first $30 \mathrm{~min}$ of the comparison when the two instruments were sampling air with different $\mathrm{CO}$ mixing ratios owing to the spatial arrangement of the aircraft.

The scattergram plot of the $\mathrm{O}_{3}$ instruments with a corresponding one to one and a weighted bivariate linear re- gression fit line are displayed in Fig. 5a. A very tight correlation of 0.96 was discovered between the data sets. A slope of $0.96 \pm 0.01$ was obtained from the weighted linear least squares fit with a positive intercept on the DLR axis of $3 \pm 1$ ppbv. Due to the small dynamic range ( $\sim 45 \mathrm{ppbv})$ and fairly large extrapolation from the main data spread to the $y-$ axis, the systematic difference between the instruments we believe can be deemed as insignificant. As with the $\mathrm{CO}$ instruments, $\mathrm{O}_{3}$ showed poor correlations over the first $30 \mathrm{~min}$ of the comparison period (Fig. 6). The data sets for this early period were poorly correlated $\left(r^{2}=0.44\right)$ owing to the manner in which the individual instruments collected the sampled air. The signal in the DLR data set was noisier compared to the MRF data owing to pressure variations which created a reduction in the ozone mixing ratios. The statistical fitted line parameters and associated uncertainties indicate that there are no significant systematic differences between the two $\mathrm{O}_{3}$ instruments. A further indication of this is implied with the ratio of the two $\mathrm{O}_{3}$ measurements as a function of the average $\mathrm{O}_{3}$ as shown in Fig. 5b. As with the $\mathrm{CO}$ instrument most of the data points are clustered around the 1.0 ratio line with $65 \%$ within $\pm 5 \%$ of the line. This is not as tight a relationship as with the $\mathrm{CO}$ instruments, primarily owing to the noisy $\mathrm{O}_{3}$ mixing ratio signals in the DLR instrument (first 30 min of the comparison), but the ratios are evenly distributed around the one value line. The maximum ratio obtained by statistical analysis was 1.19 , the lowest 0.85 , and the average value was $0.99 \pm 0.05$. This DLR/MRF $\mathrm{O}_{3}$ ratio showed no significant trend with the average $\mathrm{O}_{3}$ mixing ratios and was within the systematic difference of $4 \%$, which was indicated previously with the analysis by the bivariate linear least squares fit.

Carbon monoxide is a long lived tracer of human activity with reasonably well quantified source relationships and the covariance of $\mathrm{O}_{3}$ and $\mathrm{CO}$ has been used to constrain the anthropogenic sources of $\mathrm{O}_{3}$ (Chin et al., 1994; Parrish et al., 1993). For example ozone and CO correlations have been used to estimate the export of anthropogenicallyproduced ozone in North America (Parrish et al., 1993) 

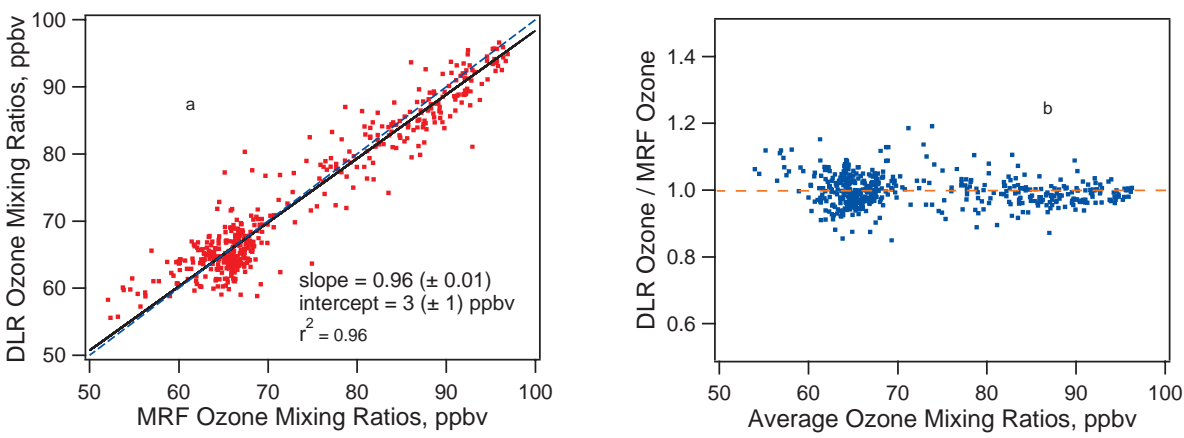

Fig. 5. Scattergram of DLR versus $M R F \mathrm{O}_{3}$ mixing ratios shown in (a) and ratios of the two instruments against the average $\mathrm{O}_{3}$ concentrations in (b). Below 50 ppbv no $\mathrm{O}_{3}$ mixing ratios were found. Solid black lines in the plot show the weighted bivariate linear least squares fit to the data. All data is averaged to $10 \mathrm{~s}$. The dashed line gives the one to one correspondence.

where $\Delta \mathrm{O}_{3} / \Delta \mathrm{CO}=0.3$. Individual instrument comparisons of the $10 \mathrm{~s}$ averaged $\mathrm{CO}$ and $\mathrm{O}_{3}$ mixing ratios are shown in Fig. 6. Four distinct periods can be identified: (1) The flight level at $8000 \mathrm{~m}$ until 13:40 GMT when the concentrations of $\mathrm{CO}$ and $\mathrm{O}_{3}$ are reasonably constant with hardly any fluctuations in the ambient mean mixing ratios of $\mathrm{CO}(\mathrm{C}-130$ : 66 \pm 2 , Falcon: $65 \pm 3$ ppbv) and $\mathrm{O}_{3}$ (C-130: 70 \pm 3 , Falcon: $71 \pm 2$ ppbv). There appears to be no apparent correlation between these two chemical species on this level. (2) The end of the flight level at $8000 \mathrm{~m}$ and the descent to $6000 \mathrm{~m}$ when layers with markedly different composition are intersected giving large, positively correlated, variations in the $\mathrm{CO}$ and $\mathrm{O}_{3}$ concentrations (these lasted between 2 and $5.5 \mathrm{~min}$ covering a corresponding distance of between 6 and $30 \mathrm{~km}$ at an IAS of $180 \mathrm{knots})$. The $\Delta \mathrm{O}_{3} / \Delta \mathrm{CO}$ ratio is greater than 1 , which is much larger than that found near the surface $(0.30)$ (Parrish et al., 1993, 1998). This is typical of the upper troposphere and is due in part to a greater $\mathrm{O}_{3}$ production efficiency compared to near the ground (Zahn et al., 2000, 2002). Further, the ratio is a function of air masses with differing origins and histories rather than simply a measure of photochemical $\mathrm{O}_{3}$ production in a single air mass. (3) The flight level at $6000 \mathrm{~m}$ until 14:13 shows a distinct negative correlation between $\mathrm{O}_{3}$ and $\mathrm{CO}$, suggesting some stratospheric influence. Also the $\mathrm{O}_{3}$ concentrations reach a maximum just above the 92 ppbv level (96.3 ppbv) defined, by Zahn et al. (2002), as the chemical tropopause over central Europe for this time of year. (4) The flight level at $6000 \mathrm{~m}$ from 14:13 onwards exhibits a similar positive correlation between $\mathrm{O}_{3}$ and $\mathrm{CO}$ as found for the second period. It is almost certain that these layers of high $\mathrm{CO}$ and $\mathrm{O}_{3}$ are due to long-range transport of pollution from North America.

\subsection{Interpretation of short-lived changes (spikes)}

During the four prominent spike episodes of $\mathrm{NO}$ and $\mathrm{NO}_{\mathrm{y}}$ displayed in Fig. 2, no significant concentration changes of $\mathrm{CO}$ were observed although a slight decrease in the $\mathrm{O}_{3}$ concentration occurred indicating a fresh pollution episode. Ta-

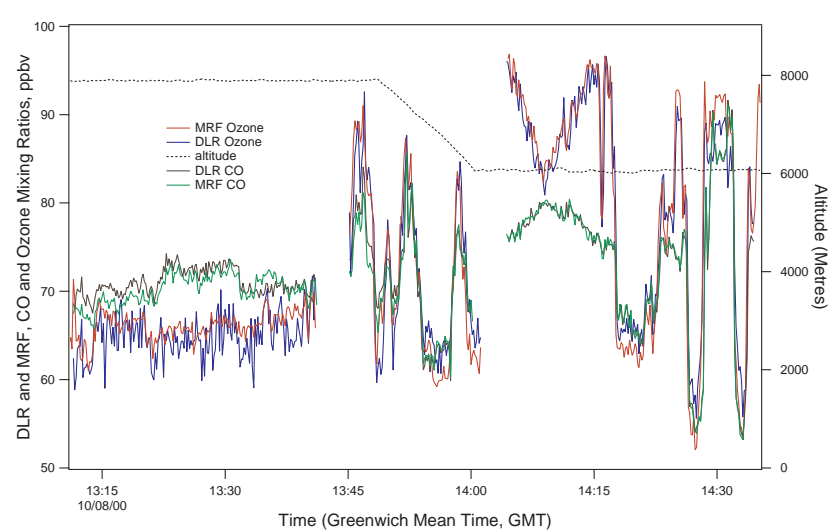

Fig. 6. Mixing ratios of $\mathrm{O}_{3}$ and $\mathrm{CO}$ for the MRF and DLR instruments between 6000 and $8000 \mathrm{~m}$ on the 10 August 2000 during the intercomparison period from 13:10 to 14:36 GMT. The data is averaged to $10 \mathrm{~s}$ and any gaps in the data are due to instrument zeroing or aircraft re-positioning.

ble 3 below displays the mixing ratios of the 4 peaks of the various data sets as well as the peak areas (in brackets) for the $\mathrm{NO}$ and $\mathrm{NO}_{\mathrm{y}}$ measurements with neither instrument having total peak precedence.

Comparison of the peak heights for the $1 \mathrm{~s}$ ratios gave the first and fourth NO peak higher on the UEA instrument suggesting that both instruments were measuring real concentration changes. Using the linear least squares fit on the $1 \mathrm{~s}$ ratios gave a slope of $1.03 \pm 0.08$ for the $\mathrm{NO}$ and a slope of $0.76 \pm 0.11$ for the $\mathrm{NO}_{\mathrm{y}}$ instruments. Most of the $\mathrm{NO}_{\mathrm{y}}$ peaks measured gave the DLR $\mathrm{NO}_{\mathrm{y}}$ higher by about $12 \%$, apart from peak one, which favoured the UEA $\mathrm{NO}_{\mathrm{y}}$ by about $2 \%$. This $2 \%$ higher value on the UEA $\mathrm{NO}_{\mathrm{y}}$ was also observed on the UEA NO and was probably due to the different spatial arrangement of the aircraft, with the NO maximum occurring closer to the UEA inlets. Apart from the $1 \mathrm{~s}$ peak ratios the areas were integrated to $y=0$ (using a trapezoidal integration) and calculated from the ambient background signal. The four peak areas show closer agreement than the corresponding 
Table 3. Aircraft instrument mixing ratios for the chemical species observed in spikes $1,2,3$, and 4 for single point $1 \mathrm{~s}$ data. The mixing ratios correspond to the highest single point during the spike period with those in brackets showing the peak area. Any missing points in the data were interpolated for the peak area integration.

\begin{tabular}{lccccc}
\hline Chemical species & Background averages, ppbv & Peak 1, ppbv & Peak 2, ppbv & Peak 3, ppbv & Peak 4, ppbv \\
\hline $\mathrm{NO}(\mathrm{C}-130)$ & 0.0198 & $0.662(3103)$ & $0.445(10073)$ & $0.506(4889)$ & $0.990(5668)$ \\
$\mathrm{NO}$ (Falcon 20) & 0.0284 & $0.463(2863)$ & $0.638(9674)$ & $0.525(5254)$ & $0.827(5608)$ \\
$\mathrm{NO}_{\mathrm{y}}$ (C-130) & 0.475 & $1.369(9723)$ & $1.093(33932)$ & $1.583(28662)$ & $2.267(26706)$ \\
$\mathrm{NO}_{\mathrm{y}}$ (Falcon 20) & 0.567 & $1.197(9531)$ & $1.681(39420)$ & $1.855(32732)$ & $2.517(29781)$ \\
$\mathrm{O}_{3}$ (C-130) & 66.1 & 61.8 & 65.5 & 92.1 & 77.2 \\
$\mathrm{O}_{3}$ (Falcon 20) & 64.6 & 61.0 & 65.6 & 92.3 & 86.7 \\
$\mathrm{CO}$ (C-130) & 69.9 & 65.1 & 70.8 & 75.4 & 75.5 \\
$\mathrm{CO}$ (Falcon 20) & 70.8 & 69.2 & 72.4 & 77.5 & 76.9 \\
\hline
\end{tabular}

single peaks for the $\mathrm{NO}$ and $\mathrm{NO}_{\mathrm{y}}$ data sets. The $\mathrm{NO}$ peak areas (C-130/Falcon 20) are all within $8 \%$ of each other indicating a close correlation between the instruments, especially at mixing ratios well above the detection limits of the instruments. The $\mathrm{NO}_{\mathrm{y}}$ peak area ratios on the other hand, often varied, ranging from 0.86 to 1.02 , with an average of 0.91 compared to 1.02 for the NO peak area ratios. This could either be due to individual instruments missing specific $\mathrm{NO}_{\mathrm{y}}$ components such as $\mathrm{HNO}_{3}$ or particulate nitrates or changes in the concentration of the $\mathrm{NO}_{\mathrm{y}}$ due to the aircraft spatial arrangement. The latter is a more conceivable reason as the least squares fit correlation coefficients shows close agreement between the instruments over the comparison period.

The spikes of predominantly NO are presumably due to exhaust plumes of commercial aircraft that have passed in the last few hours, examples of which have been measured previously by Schlager et al. (1997) and Klemm et al. (1998). Lightning could conceivably be another source (Tie et al., 2001) of increased NO but there had been no positive indication of lightning episode occurring over the previous few days. An estimation of the age of these spikes can usually be obtained by the $\mathrm{NO} / \mathrm{NO}_{\mathrm{y}}$ mixing ratios (Ridley et al., 1994). Fresh aircraft emissions would be expected to have high NO content, since jet engines emit odd nitrogen mostly in the form of $\mathrm{NO}_{\mathrm{x}}$ (Schumann, 1997), giving a higher $\mathrm{NO} / \mathrm{NO}_{\mathrm{y}}$ ratio than normally expected for this altitude. Over New Mexico (Ridley et al., 1994), and over the Northeast Atlantic (Klemm et al., 1998), NO/NO ${ }_{\mathrm{y}}$ ratios greater than 0.6 were calculated in aircraft flight corridors. On this flight, no strong evidence of fresh aircraft emissions was obtained. The 4 major $1 \mathrm{~s}$ peak ratios after averaging were found to be $0.41 \pm 0.09$ for the UEA instruments whilst the DLR ratios were slightly lower at $0.34 \pm 0.06$. Ratios of the $\mathrm{NO} / \mathrm{NO}_{\mathrm{y}}$ areas are a more accurate representation of the peaks and produced even lower averaged values, namely, $0.25 \pm 0.07$ and $0.21 \pm 0.06$ for the UEA and DLR instruments, respectively. It could well be that these peaks observed on both independent instruments were due to aircraft emissions but they have had considerable time to be diluted or age pho- tochemically and give lower $\mathrm{NO} / \mathrm{NO}_{\mathrm{y}}$ ratios than expected. The NO/NO ratios are 10 -fold higher than the background ratios of $0.04 \pm 0.02$ for the UEA and $0.05 \pm 0.01$ for the DLR instruments, indicating that some pollution episode had occurred.

\section{Summary}

In this paper we have shown that several of the chemical tracer instruments used on board the C-130 and Falcon 20 appear to be functioning correctly and are in good agreement with each other. Data for $\mathrm{NO}, \mathrm{NO}_{\mathrm{y}}, \mathrm{O}_{3}, \mathrm{CO}$ were obtained from EXPORT aircraft measurements carried out over southern Germany on 10 August 2000 and correlations between species on individual instruments were studied. The differences in the correlations between instruments allow an assessment of the measurement capabilities determined by the accuracy, precision and the possibility of ambient interference on the instruments. The $\mathrm{NO}$ and $\mathrm{NO}_{\mathrm{y}}$ correlations, without the spikes, give a very clear indication of the close agreement, within statistical estimated instrument precision, of the two instruments and that both appear to be operating satisfactory over a wide range of observed values (101000 pptv). High mixing ratios well above the detection limits and a large dynamic range of measurements on both instruments helped to provide clear correlation coefficients and the agreement over the air masses sampled demonstrates that significant interferences in the measurements are absent. Variations in mixing ratios between instruments appeared to be random and reflect real differences in air masses sampled and can be assumed to be due to spatial arrangements of the aircraft. The degree of agreement lends confidence to the accuracy of all observed measurements and indicates the accuracy to be within the uncertainties quoted in Tables 1 and 2.

Statistical analysis of the CO data was found to give tight correlation coefficients and low slope gradients with the dynamic range that was observed. Although the mixing 
ratio differences during the first $30 \mathrm{~min}$ at the higher altitude has not been fully solved, the instruments appear to be both functioning correctly. It is very likely that the differences observed on both instruments were due to air with different $\mathrm{CO}$ mixing ratios being sampled than any instrument uncertainties. This is confirmed by the consistent agreement between the instruments within their estimated precision and indicates the absence of any major interference. Qualitative estimates of ambient $\mathrm{CO}$ concentrations can be derived from this intercomparison between the two instruments.

$\mathrm{O}_{3}$ was also found to give very close agreement throughout the intercomparison period. The higher signal to noise ratios over the first $30 \mathrm{~min}$ of the intercomparison for the DLR $\mathrm{O}_{3}$ instrument can be explained by the sampling method employed. A significantly higher noise was observed for the DLR $\mathrm{O}_{3}$ at a given $\mathrm{O}_{3}$ volume mixing ratio for pressures lower than sea surface pressure resulting in a reduced number of $\mathrm{O}_{3}$ molecules in the cell compared to the C-130 $\mathrm{O}_{3}$ measurement. Statistical analyses indicated that the data sets were closely correlated and well within the estimated precision of the instruments. Errors that were initially found on the MRF instrument associated with the temperature sensor were corrected before final data submission.

The $\mathrm{NO}, \mathrm{NO}_{\mathrm{y}}, \mathrm{O}_{3}$ and $\mathrm{CO}$ datasets, from the different aircraft, used during EXPORT, can now be combined with confidence. This provides greater coverage of data, for use in computer simulation or transport studies etc, and gives 'added value' to both experiments. This particular form of comparison flight also lends credibility to composite studies of airborne observations, for example the type detailed by Emmons et al. (2000). The discrepancies for the missing $\mathrm{NO}_{\mathrm{y}}$ are not significant within the combined uncertainties of the two instruments. Additionally, differences in the inlet design may result in different efficiencies of aerosol sampling by the two instruments leading to the sampling of different amounts of particulate nitrate, although slightly different air mass sampling cannot be totally ruled out.

Acknowledgements. MRF for the support and help in establishing instruments on board the C-130 aircraft. S. Bauguitte for the development of the $\mathrm{NO}_{\mathrm{x}, \mathrm{y}}$ instrument at the NOAA workshop in Boulder, Colorado. Those at Boulder such as F. Fehsenfeld, M. Buhr, T. Ryerson, D. Sueper and D. Parrish who helped with the building of the $\mathrm{NO}_{\mathrm{x}, \mathrm{y}}$ instrument and the statistical package for the bivariate linear regression analysis. UK Natural Environment Research Council (NERC) for funding under grant number NER/A/S/1999/00082.

\section{References}

Baugiutte, S. J. B.: A study of tropospheric reactive nitrogen oxides in the North Atlantic Region, Phd. Thesis, UEA, Norwich, 2000.

Chin, M., Jacob, D. J., Munger, J. W., Parrish, D. D., and Doddridge, B. G.: Relationship of ozone and carbon monoxide over North America, J. Geophys. Res., 99, 14 565-14 573, 1994.

Day, D. A., Dillon, M. B., Wooldridge, P. J., Thornton, J. A., Rosen, R. S., Wood, E. C., and Cohen, R. C.: On alkyl nitrates,
$\mathrm{O}_{3}$, and the "missing NOy", J. Geophys. Res., 108 D16, 4501, doi:10.1029/2003JD003685, 2003.

Drummond, J. W., Volz, A., and Ehhalt, D. H.: An optimized chemiluminescence detector for tropospheric NO measurements, J. Atmos. Chem., 2, 287-306, 1985.

Drummond, J. W., Volz, A., and Ehhalt, D. H.: Measurements of nitric oxide between $0-12 \mathrm{~km}$ altitude and $67^{\circ} \mathrm{N}$ to $60^{\circ} \mathrm{S}$ latitude obtained during STRATOZ III, J. Geophys. Res., 93, D12, $15831-15849,1988$.

Emmons, L. K., Hauglustaine, D. A., Müller, J.-F., Carroll, M. A., Brasseur, G. P., Brunner, D., Staehelin, J., Thouret, V., and Marenco, A.: Data composites of airborne observations of tropospheric ozone and its precursors, J. Geophys. Res., 105, D16, 20 497-20 538, 2000.

Fahey, D. W., Eubank, C.S., Hübler, G., and Fehsenfeld, F. C.: Evaluation of a catalytic reduction technique for the measurement of total reactive odd nitrogen $\mathrm{NO}_{\mathrm{y}}$ in the atmosphere, J. Atmos. Chem., 435-468, 1985.

Fehsenfeld, F.C., Drummond, J. W., Roychowdhury, U. K., Galvin, P. J., Williams, E. J., Buhr, M. P., Parrish, D. D., Hübler, G., Langford, A. O., Calvert, J. G., Ridley, B. A., Grahek, F., Heikes, B. G., Kok, G. L., Shetter, J. D., Walega, J. G., Elsworth, C. M., Norton, R. B., Fahey, D. W., Murphy, P. C., Hovermale, C., Mohnen, V. A., Demerjian, K. L., Mackay, G. I., and Schiff, H. I.: Intercomparison of $\mathrm{NO}_{2}$ measurements techniques, J. Geophys. Res., 95, D4, 3579-3597, 1990.

Gerbig, C., Kley, D., Volz-Thomas, A., Dewey, K., and Haaks, D. Fast-response resonance fluorescence $\mathrm{CO}$ measurements aboard the C-130: Instrument characterization and measurements made during North Atlantic Regional Experiment.: J. Geophys. Res., 101, D1, 1699-1704, 1996.

Gerbig, C., Schmitgen, S., Kley, D., Volz-Thomas, A., Dewey, K. and Haaks, D.: An improved fast-response vacuum-UV resonance fluorescence CO instrument, J. Geophys. Res., 104, D1, 1699-1704, 1999.

Holloway, J. S., Jacoubek, R. O., Parrish, D. D., Gerbig, C., VolzThomas, A., Schmitgen, S., Fried, A., Wert, B., Henry, B., and Drummond, J. R.: Airborne Intercomparison of Vacuum Ultraviolet Fluorescence and Tunable Diode Laser Absorption Measurements of Tropospheric Carbon Monoxide, J. Geophys. Res., 105, D19, 24 251-24 261, 2000.

Hov, O., Flatoy, F., Solberg, S., Schmidbauer, N., Dye, C., Foot, J. S., Dewey, K., Kent, J., Richter, H., Kaye, A., Kley, D., Schmitgen, S., Penkett, S. A., Reeves, C., Bandy, B., Brough, N., Green, T., Mills, G., Law, K., Plantevin, P-H., Savage, N., Arnold, S., Lobb, M., Evans, M., O’Connor, F., Pyle, J., Beekmann, M., Kowol-Santen, J., Dugault, E., Monks, P. S., Edwards, G. D., and McQuaid, J.: Maximum Oxidation Rates in the Free Troposphere (MAXOX), Final Report, 2-36, ENV4-CT97_0525, Brussels, EU, 2000.

Hübler, G., Fahey, D. W., Ridley, B. A., Gregory, G. L., and Fehsenfeld, F. C.: Airborne measurement of total reactive odd nitrogen (NOy), J. Geophys. Res., 97, 9833-9850, 1992.

Klemm, O., Stockwell, W. R., Ziereis, H., and Schlager, H.: Measurements of nitrogen oxides from aircraft in the northeast Atlantic flight corridor, J. Geophys. Res., 103, D23, 31 217-31 229, 1998.

Kley, D. and McFarland, M.: Chemiluminescence detector for NO and $\mathrm{NO}_{2}$ Atmos. Technol., 12, 63-69, 1980. 
Kondo, Y., Kawakami, S., Koike, M., Fahey, D. W., Nakajima, H., Zhao, Y., Toriyama, N., Kanada, M., Sachse, G. W., and Gregory, G. L.: Performance of an aircraft instrument for the measurement of $\mathrm{NO}_{\mathrm{y}}$, J. Geophys. Res., 102, D23, 28 663-28 671, 1997.

Neri, F. G., Saitta, G., and Chiofalo, S.: An accurate and straightforward approach to line regression analysis of error-affected experimental data, J. Phys. E Sci. Instrum., 22, 215-217, 1989.

Neuman, J. A., Huey, L. G., Ryerson, T. B., and Fahey, D. W.: Study of inlet materials for sampling atmospheric nitric acid, Environ. Sci. Technol., 33, 1133-1136, 1999.

Newell, R. E., Wu, Z.-X., Zhu, Y., Hu, W., Browell, E. V., Gregory, G. L., Sachse, G. W., Collins Jr, J. E., Kelly, K. K., and Liu, S. C.: Vertical fine-scale atmospheric structure measured from NASA DC-8 during PEM-West A, J. Geophys. Res., 101, 19431960, 1996.

Parrish, D. D., Holloway, J. S., Trainer, M., Murphy, P. C., Forbes G. L., and Fehsenfeld, F. C.: Export of North American ozone pollution to the north Atlantic ocean, Science, 259, 1436-1439, 1993.

Parrish, D. D., Buhr, M. P., Trainer, M., Norton, R. B., Shimshock, J. P., Fehsenfeld, F. C., Anlauf, K. G., Bottenheim, J. W., Tang, Y. Z., Wiebe, H. A., Roberts, J. M., Tanner, R. L., Newman, L., Bowersox, V. C., Olszyna, K. J., Bailey, E. M., Rodgers, M. O., Wang, T., Berresheim, H., Roychowdhury, U. K., and Demerjian, K. L.: The total reactive oxidised nitrogen levels and the partitioning between the individual species at six rural sites in eastern North America. J. Geophys. Res. 98, D2, 2927-2939, 1993.

Parrish, D. D., Trainer, M., Holloway, J. S., Yee, J. E., Warshawshy, M. S., Fehsenfeld, F. C., Forbes G. L., and Moody, J. L.: Relationships between ozone and carbon monoxide at surface sites in the North Atlantic region, J. Geophys. Res., 103, 13 357-13 376, 1998.

Penkett, S. A., Bandy, B. J., Reeves, C. E., McKenna, D., and Hignett, P.: Measurements of peroxides in the atmosphere and their relevance to the understanding of global tropospheric chemistry, Faraday Discuss., 100, 155-174, 1995.

Ridley, B. A., Carroll, M. A., Torres, A. L., Condon, E. P., Sachse, G. W., Hill, G. F., and Gregory, G. L.: An intercomparison of results from ferrous sulphate and photolytic converter techniques for measurements of $\mathrm{NO}_{\mathrm{x}}$ made during the NASA GTE/CITE 1 aircraft program, J. Geophys. Res., 93, No. D12, 15 803-15811, 1988.

Ridley, B. A., Walega, J. G., Dye, J. E., and Grahek, F. E.: Distribution of $\mathrm{NO}, \mathrm{NO}_{\mathrm{x}}, \mathrm{NO}_{\mathrm{y}}$, and $\mathrm{O}_{3}$ to $12 \mathrm{~km}$ altitude during the summer monsoon over New Mexico, J. Geophys. Res., 99, D12, 25 519-25 534, 1994.

Ridley, B. A., Walega, J., Montzka, D., Grahek, F., Atlas, E., Flocke, F., Stroud, V., Dreary, J., Gallant, A., Boudries, H., Bottenheim, J., Anlauf, K., Worthy, D., Sumner, A. L., Splawn, B., and Shepson, P.: Is the arctic surface layer a source and sink of $\mathrm{NO}_{\mathrm{X}}$ in winter/spring? J. Atmos. Chem., 36, 1-22, 2000.
Ryerson, T. B., Huey, L. G., Knapp, K., Neuman, J. A., Parrish, D. D., Sueper D. T., and Fehsenfeld, F. C.: Design and initial characterisation of an inlet for gas-phase $\mathrm{NO}_{\mathrm{y}}$ measurements from aircraft, J. Geophys. Res., 104, 5483-5492, 1999.

Schlager, H., Konopka, P., Schulte, P., Schumann, U., Ziereis, H., Arnold, F., Klemm, M. Hagen, D. E., Whitefield, P. D., and Ovarlez, J.: In situ observations of air traffic emission signatures in the North Atlantic flight corridor, J. Geophys. Res., 102, 10739 $10750,1997$.

Schumann, U.: The impact of nitrogen oxides emissions from aircraft upon the atmosphere at flight altitudes - results from the aeronox project, Atmos. Environ., 31, 12, 1723-1733,1997.

Stehr, J. W., Dickerson, R. R., Hallock-Waters, K. A., Doddridge, B. G. and Kirk, D.: Observations of $\mathrm{NO}_{\mathrm{y}}, \mathrm{CO}$ and $\mathrm{SO}_{2}$ and the origin of reactive nitrogen in the eastern United States, J. Geophys. Res., 105, D3, 3553-3563, 2000.

Tie, X., Zhang, R., Brasseur, G., Emmons, L., and Lei, W.: Effects of Lightening on reactive nitrogen and nitrogen reservoir species in the troposphere, J. Geophys. Res., 106, 3167-3178, 2001.

Williams, E. J., Roberts, J. M., Baumann, K., Bertman, S. B., Buhr, S. Norton, R. B., and Fehsenfeld, F. C.: Variations in $\mathrm{NO}_{\mathrm{y}}$ composition at Idaho Hill, Colarado, J. Geophys. Res. 102, D5, 6297-6314, 1997.

Williams, E. J., Baumann, K., Roberts, J. M., Bertmann, S. B., Norton, R. B., Fehsenfeld, F. C., Springston, S. R., Nunnermacker, L. J., Newman, L., Olszyna, K., Meager, J., Hartsell, B., Edgerton, E., Pearson, J. R., and Rodgers, M. O.: Intercomparison of ground based $\mathrm{NO}_{\mathrm{y}}$ measurement techniques. J. Geophys. Res., 103, D17, 22 261-22 280, 1998.

Zahn, A., Brenninkmeijer, C. A. M., Maiss, M., Scharffe, D. H., Crutzen, P. J., Hermann, M., Heintzenberg, J., Wiedensohler, A., Gusten, H., Heinrich, G., Fischer, H., Cuijpers, J. W. M., and van Velthoven, P. F. J.: Identification of extratripical two-way troposphere-stratosphere mixing based on CARIBIC measurements of $\mathrm{O}_{3}, \mathrm{CO}$ and ultrafine particles, J. Geophys. Res., 105, 1527-1535, 2000.

Zahn, A., Brenninkmeijer, C. A. M., Asman, W. A. H., Crutzen, P. J., Heinrich, G., Fischer, H., Cuijpers, J. W. M., and van Velthoven, P. F. J.: Budgets of $\mathrm{O}_{3}$ and $\mathrm{CO}$ in the upper troposphere: CARIBIC passenger aircraft results 1997-2001, J. Geophys. Res., 107, ACH 6, doi:10.1029/2001JD001529, 2002.

Zenker, T., Fischer, H., Nikitas, C., Parchatka, U., Harris, G. W., Mihelcic, D., Müsgen, P., Pätz, H. W., Schultz, M.. VolzThomas, A., Schmitt, R., Behmann, T., Weißenmayer, M., and Burrows, J. P.: Intercomparison of $\mathrm{NO}, \mathrm{NO}_{2}, \mathrm{NO}_{\mathrm{y}}, \mathrm{O}_{3}$ and $\mathrm{RO}_{\mathrm{x}}$ measurements during the oxidising capacity $\mathrm{f}$ the tropospheric atmosphere (OCTA) campaign 1993 in Izana. J. Geophys. Res., 103, D11, 13 615-13 634, 1998.

Ziereis, H., Schlager, H., and Schulte, P.: NO, $\mathrm{NO}_{\mathrm{y}}$, and $\mathrm{O}_{3}$ intercomparisons during POLINAT 2, in Pollution From Aircraft Emissions in the North Atlantic Flight Corridor (POLINAT 2), Air. Pollut. Res. Rep. 68, edited by Schumann, U., 55-63, Eur. Comm., Luxembourg, 1999. 